\title{
Effects of Bothriochloa ischaemum Characteristics Induced by Nitrogen Addition on the Process of Slope Runoff and Sediment Yield
}

\author{
Panpan Li ${ }^{1}$, Binbin $\mathrm{Li}^{2}$, Jianfang Wang ${ }^{1}$, Guobin Liu ${ }^{1 *}$ \\ ${ }^{1}$ State Key Laboratory of Soil Erosion and Dryland Farming on the Loess Plateau, \\ Institute of Soil and Water Conservation, Northwest A\&F University, Yangling, Shaanxi, China \\ ${ }^{2}$ University of Chinese Academy of Sciences, Beijing, China
}

Received: 29 December 2019

Accepted: 16 March 2020

\begin{abstract}
Nitrogen deposition has great effects on vegetation characteristics and then affects soil erosion. This study was conducted to quantify the effects of vegetation characteristics induced by nitrogen addition on runoff and sediment yield. The Bothriochloa ischaemum (Linn.) Keng. was planted and applied $\mathrm{NH}_{4} \mathrm{NO}_{3}$ at levels of $0,2.5,5$, and $10 \mathrm{~g} \mathrm{~N} \mathrm{~m}^{-2} \mathrm{yr}^{-1}$ for three years with the bare soil for control. Then all treatments were subjected to simulated rainfall $\left(1.0,1.5\right.$, and $\left.2.0 \mathrm{~mm} \mathrm{~min}{ }^{-1}\right)$. Results showed that nitrogen addition increased plant coverage, height, and aboveground biomass of $\mathrm{N}_{2.5}, \mathrm{~N}_{5}$ and $\mathrm{N}_{10}$ treatments, while the root mass density of $\mathrm{N}_{10}$ was the minimum. The grassplots significantly delayed runoff starting time, reduced runoff and sediment yield. With nitrogen addition increasing, runoff starting time delayed and runoff amount decreased, although no significant difference of runoff amount was found under the high rainfall intensity. Moreover, sediment yield would be well estimated by runoff mount, coverage and root mass density with a power function. $5 \mathrm{~g} \mathrm{~N} \mathrm{~m}^{-2} \mathrm{yr}^{-1}$ seems the optimal nitrogen level in controlling soil loss due to its minimum sediment yield. The different effects of nitrogen addition on grassland community and soil erosion process identified in this study may facilitate the simulation and prediction of soil erosion in semiarid grasslands under future scenarios of global change.
\end{abstract}

Keywords: nitrogen addition, coverage, root mass density, soil erosion, the Loess Plateau

\section{Introduction}

Soil erosion can cause soil fertility loss and reduce land productivity, which has been identified as a critical

*e-mail: gbliu@ms.iswc.ac.cn and complex environmental problem worldwide [1]. Rainfall and overland flow are the driving forces behind soil erosion processes [2]. Rainfall intensity is a common indicator used to reflect rainfall characteristics, with higher intensity representing higher raindrop kinetic energy during the rain splash erosion process. In addition, overland flow velocity is also an 
important parameter to describe the hydrodynamic characteristics of overland flow, and higher overland flow velocity can strengthen runoff shear stress and accelerate soil detachment and transport [3]. Previous studies have shown that soil erosion may vary with rainfall intensity positively as a linear [4] or power function [5], and sediment yield rate under high rainfall intensity $\left(1.5 \mathrm{~mm} \mathrm{~min}^{-1}\right)$ is between about 5.2 and 17.4 times higher than that under low rainfall intensity $\left(0.75 \mathrm{~mm} \mathrm{~min}^{-1}\right)$ over a variety of soil types [6]. In addition, soil detachment rate [1] refers to the amount of soil loss per unit time and per unit area under runoff erosion, and the relationship between soil detachment rate and mean flow velocity has been described as power function of $D_{c}=0.344 V^{3.18}\left(\mathrm{R}^{2}=0.91\right)$ [7].

Vegetation would prevent soil erosion significantly by intercepting raindrops, delaying runoff time, increasing soil roughness and infiltration capacity, and reducing runoff generation and velocity [8]. Generally, the effectiveness of vegetation in controlling soil loss depends on vegetation types [9]. Vegetation types can have a great impact on the stability and erosion of soil aggregates due to their various soil organic carbon contents and root morphology characteristics [10]. A spatial analyss applying ArcGIS and SWAT model of the Yanhe River basin in the Loess Plateau showed that forestland was more effective in runoff reduction than that of grassland, while the sediment yield reduction of the two land use was nearly equal [11]. Besides, some studies indicated that grassland generated equal runoff amount and more soil loss compared to forestland [12]. However, it also has been concluded that high coverage $(85.78 \%)$ of grassland produced the lowest soil loss $\left(76.50 \mathrm{~g} \cdot \mathrm{m}^{-2}\right)$, which was between $58.8 \%$ and $73.4 \%$ lower than soil loss under other vegetation types (i.e. shrubs, deciduous trees, and evergreen trees) [13]. In addition to different grassland, vegetation coverage was the dominant factor in inhibiting soil loss, and the runoff and sediment yield of different land-use types followed the trend: cultivated land $>$ cultivated land + artificial grassland $>$ cultivated land + abandoned land $>$ artificial grassland $>$ abandoned land [14].

The effects of vegetation on soil erosion involve both aboveground and belowground components, including plant coverage, aboveground biomass, litter coverage, and root characteristics. Vegetation cover can reduce soil loss greatly by increasing in the interception of raindrops, which reduces raindrop kinetic energy and overland flow [15, 16]. Moreover, it can increase hydraulic roughness, since plant stems reduce flow velocity [17]. Vegetation coverage is a common parameter for quantifying the relationship between vegetation and soil erosion [18]. An analysis between soil erosion modulus and grass coverage in grasslands indicated that the soil erosion modulus $(E)$ had a negative index relation with coverage $(C)$ $\left(E=1943.4 \mathrm{e}^{-0.027} C\right)[19]$. There was also a negative logarithmic relationship between sediment yield rate $(S Y R)$ and vegetation coverage $(C)$ expressed as
$S Y R=1.077-2.911 \ln (C)[17]$. Roots can also reduce soil erosion effectively by improving soil structure, which reduces soil erodibility and increases infiltration capacity [15]. It has been shown that roots decrease soil loss by $46 \%$ to $70 \%$ under different plant patterns in Artemisia capillaries Thunb., when compared to plant canopies. Moreover, fibrous roots were more significant in reducing soil erosion than tap roots, and the former could reduce more sediment yield by $93.2 \%$ than that of the later [20]. In addition, root surface area density and root mass density were central negatively correlated indicators affecting sediment rate [21].

Soil nitrogen is the major determinants and indicators of soil fertility, which is closely related to soil productivity [22]. Nitrogen is an essential and limiting nutrient for plant tissue growth, especially in semi-arid ecosystems, and it strongly determines the allocation of biomass for plant organs [23, 24]. With the increase of nitrogen deposition rate, characteristics of vegetation, such as coverage, net primary production and root mass, changed significantly $[25,26]$. It has been concluded that increasing nitrogen addition would significantly increase vegetation coverage [27]. Some studies have also indicated that nitrogen addition has no significant effect on aboveground biomass or coverage when the amount of nitrogen addition is too high [28]. The net primary production (NPP) is generally considered to be the amount of dry organic matter produced by plants per unit time and per unit area [29]. Tang et al. [30] indicated that the NPP of grassland increased by $3 \%$ with a nitrogen deposition rate increase of $0.1 \mathrm{~g} \mathrm{~m}^{-2} \mathrm{yr}^{-1}$. For forests, on the other hand, the aboveground NPP was less sensitive to nitrogen, increasing only $0.4 \%$ as the available nitrogen increased $0.1 \mathrm{~g} \mathrm{~m}^{-2} \mathrm{yr}^{-1}$ [31]. The response of plant roots to nitrogen addition was significant, and roots undergoing nitrogen addition treatment $\left(1.0 \mathrm{mg} \mathrm{NH}_{4}-\mathrm{N} \mathrm{L}^{-1}\right)$ were $4.23,7.85$, and 9.10 times greater in dry biomass, mean surface area, and root length (respectively) than that of the control treatment with no nitrogen $[32,33]$. When the nitrogen level is too high, the positive impact of nitrogen on roots will decrease or even limit root growth [34].

On the Loess Plateau, soil erosion is severe. Mean annual soil erosion rates in this region range from 5000 to $10000 \mathrm{t} \mathrm{km}^{-2} \mathrm{yr}^{-1}$ [35]. Series of ecological restoration projects have been implemented to control soil erosion and restore the disturbed ecosystem. Many farmlands were forcefully abandoned, especially for the implementation of the "Grain for Green" project, and the natural vegetation succession was allowed to begin [36]. Consequently, the area of grassland increased rapidly and accounted for $41.7 \%$ $\left(2.6 \times 10^{5} \mathrm{~km}^{2}\right)$ of the total area of the Loess Plateau at the end of 2010 [37]. The contribution of grassland to reducing soil erosion was important, for it is the main vegetation type and covers a large area of the Loess Plateau. As mentioned above, nitrogen deposition could greatly affect the characteristics of vegetation. 
According to data from the year 2000, the lowest nitrogen deposition rate was in the Arctic (less than 0.2 to $0.3 \mathrm{~g} \mathrm{~N} \mathrm{~m}^{-2} \mathrm{yr}^{-1}$ ), and in some regions the rate ranged from 1 to $2 \mathrm{~g} \mathrm{~N} \mathrm{~m}^{-2} \mathrm{yr}^{-1}$. However, it rose to $6 \mathrm{~g} \mathrm{~N} \mathrm{~m}^{-2} \mathrm{yr}^{-1}$ in some highly polluted areas [38]. What's more, the global nitrogen deposition rate in 2030 may be 2 to 2.5 times higher than it was in 2000 [39]. In China, the average of atmospheric wet nitrogen deposition increased from 1.11 to $1.39 \mathrm{~g} \mathrm{~m}^{-2} \mathrm{yr}^{-1}$ between 1980 and 2010: an increase of nearly 25\% [40]. By 2013, the average rate of nitrogen deposition was about $1.80 \mathrm{~g} \mathrm{~m}^{-2} \mathrm{yr}^{-1}$ in China [41], and it ranged between approximately 0.83 and $2.06 \mathrm{~g} \mathrm{~m}^{-2} \mathrm{yr}^{-1}$ on the Loess Plateau in 2006 [42]. Therefore, nitrogen deposition will have a significant impact on the ecosystem of this area.

As a complex and related system, the change of nitrogen deposition rate will affect plant characteristics and further affect soil erosion process. Although numerous studies have mentioned that vegetation characteristics were affected by nitrogen deposition, however, the internal effects of vegetation characteristics induced by nitrogen deposition on the process of soil erosion has not received much attention. As mentioned above, vegetation characteristics of coverage, height, aboveground biomass and root mass would be changed and even be redistributed due to the nitrogen deposition, such as nitrogen deposition would increase the aboveground biomass but decrease the root mass. In general, the effects of vegetation on soil erosion process presented through the aboveground and underground characteristics as a whole. Hence, the soil erosion process might be changed due to varied or redistributed vegetation characteristics induced by nitrogen deposition, which still needs further study. In this paper, the typical herbage of Bothriochloa ischaemum (Linn.) Keng. (abbreviated as B. ischaemum) on the Loess Plateau was selected and applied $\mathrm{NH}_{4} \mathrm{NO}_{3}$ with different levels to simulate the effects of nitrogen deposition on the grassland in this region, and aimed to detect the varied characteristics of coverage, plant height, aboveground biomass and root mass density in $B$. ischaemum under different nitrogen deposition rate, to reveal the effects of $B$. ischaemum characteristics induced by nitrogen deposition on the runoff and sediment yield process, and to develop a model to estimate sediment yield based on the characteristics of precipitation and vegetation on the Loess Plateau.

\section{Material and Methods}

\section{Experimental Treatments Design}

To detect the effects of vegetation characteristics induced by nitrogen deposition on the process of soil erosion, four nitrogen addition treatments with B. ischaemum were designed and a bare loess soil treatment was selected as control, then all treatments were subjected to the rainfall striking under three rainfall intensities with the slope gradient of 26.8 $\%$. The B. ischaemum was planted in a steel tank for three years, which was $2 \mathrm{~m}$ in length, $1 \mathrm{~m}$ in width and $0.5 \mathrm{~m}$ in depth. According to the global nitrogen deposition levels [43,44] and the amounts of nitrogen deposition in China [42, 45], four nitrogen addition levels of $0,2.5,5$ and $10 \mathrm{~g} \mathrm{~m}^{-2} \mathrm{yr}^{-1}$ were designed and the $\mathrm{NH}_{4} \mathrm{NO}_{3}$ was applied to $B$. ischaemum as the nitrogen sources to simulate the nitrogen deposition. For each nitrogen addition level and the control treatment of bare soil, they were all replicated three times. Totally, fortyfive rainfalls were conducted.

\section{Experimental Conditions}

This experiment was conducted at the State Key Laboratory of Soil Erosion and Dryland Farming on the Loess Plateau, Yangling, China. The simulated rainfall system used in the experiment was a sidesprinkle device, and the rainfall height was $16 \mathrm{~m}$, which satisfies the condition that all raindrops reach terminal speed. The rainfall intensity varied from 0.67 to $4.33 \mathrm{~mm} \mathrm{~min}^{-1}$ with rainfall uniformity above $80 \%$, which is approximately equivalent to natural raindrop distribution and size.

\section{Experiment Preparation and the Plantation of B. ischaemum}

Steel tanks (Length $\times$ Width $\times$ Depth $=2.0 \mathrm{~m} \times$ $1.0 \mathrm{~m} \times 0.5 \mathrm{~m}$ ) used in the experiment were all filled with loessal soil, which was collected from the top soil (0 to $20 \mathrm{~cm}$ ) of natural grassland from Ansai County (Shaanxi Province). Before filling the soil, the slope of steel plot was adjusted to $0 \%$ to ensure the convenience of soil filling and the uniformity of the soil. Plant roots and other debris were removed with a $2 \mathrm{~mm}$ sieve. For the process of soil filling, $5 \mathrm{~cm}$ of sand was laid at the bottom of the steel plot to ensure that the water could penetrate smoothly and evenly. In order to ensure the uniformity of the soil bulk density in the steel plot, the

Table 1. Physical and chemical properties of the soil used in the experiment.

\begin{tabular}{|c|c|c|c|c|c|}
\hline \multirow{2}{*}{ Soil type } & \multicolumn{3}{|c|}{ Particle composition $/ \%$} & \multirow{2}{*}{$\begin{array}{c}\text { Content of soil organic } \\
\text { matter } / \mathrm{g} \cdot \mathrm{kg}^{-1}\end{array}$} & $\begin{array}{c}\text { Content of total } \\
\text { nitrogen } / \mathrm{g} \cdot \mathrm{kg}^{-1}\end{array}$ \\
\cline { 2 - 4 } & Sand & Silt & Clay & 4.125 & 0.212 \\
\hline Loessal soil & 23.09 & 63.99 & 12.92 & \\
\hline
\end{tabular}


total soil weight was calculated by the fill volume and the designed bulk density $\left(1.2 \mathrm{~g} \mathrm{~cm}^{-3}\right)$. And then the prepared soil was divided into 4 times to fill the steel plot. The thickness of filled soil every time was $10 \mathrm{~cm}$. For each layer, the soil surface was raked lightly before packing the next layer to eliminate the discontinuity. The basic information regarding these filled soil properties is shown in Table 1 .

For each steel tank, the B. ischaemum was seeded by digging a $3 \mathrm{~mm}$ aperture in the surface soil with the plant spacing of $20 \mathrm{~cm}$ (fifty plants in total). To ensure the survival rate, the soil surface was covered with straw mat and watered regularly. After 1 year of growth, $\mathrm{NH}_{4} \mathrm{NO}_{3}$ was sprayed under four designed nitrogen amounts onto the soil surface to simulate the nitrogen deposition for 3 consecutive years. During the growing season, from June to August, the plot was sprayed six times for each simulated year.

\section{Simulated Rainfall Process and Measurements}

The simulated rainfall experiments were carried out at the end of the growing season for B. ischaemum (late September in 2015) with a rainfall duration of 90 minutes and rainfall intensities of 1.0, 1.5, and $2.0 \mathrm{~mm} \mathrm{~min}{ }^{-1}$. Before rainfall, the coverage of $B$. ischaemum was measured using a digital camera and plant height was measured with a tape. Based on the results of the pre-experiment, the runoff rate changed greatly during the first 30 minutes, so runoff and sediment mixed samples were collected every 2 minutes with runoff buckets. During the remaining 60 minutes, the runoff rate tended to be stable, and the samples were collected every 4 minutes during this period. During the experiment, the runoff time was recorded. After the rainfall was stopped, the runoff-sediment samples were weighed. Then, the sediment was deposited in order to adequately separate from the water, dried in an air-forced oven at $105^{\circ} \mathrm{C}$ until they reached a constant weight $(48 \mathrm{~h})$, and finally weighed. The difference between runoff-sediment weight and sediment weight for a given sample was the runoff. The B. ischaemum roots were taken out by using a steel ring $(16 \mathrm{~cm}$ in diameter by $25 \mathrm{~cm}$ in height) and washed. Then, the root was dried in an air-forced oven at $65^{\circ} \mathrm{C}$ until it reached constant weight $(48 \mathrm{~h})$ in order to calculate the root mass density. The aboveground part of the $B$. ischaemum was clipped and dried in an air-forced oven at $65^{\circ} \mathrm{C}$ until it reached a constant weight $(48 \mathrm{~h})$ for calculating the aboveground biomass.

\section{Data Analysis}

Multiple comparison analysis was applied to determine the differences of characteristics in B. ischaemum among different nitrogen addition treatments, as well as the differences of the runoff starting time among all treatments under three rainfall intensities. To investigate the factors affecting sediment yield, Pearson's correlation analysis was performed between runoff amount, plant coverage, plant height, aboveground biomass and root mass density. Stepwise regression analysis was used to determine the relationship between sediment yield and the characteristics of rainfall or vegetation, and the performance of the regression was evaluated by the coefficient of determination $\left(\mathrm{R}^{2}\right)$ and Nash-Sutcliffe efficiency coefficient (NSE). Nash-Sutcliffe efficiency coefficient (abbreviated as NSE) is generally used to verify the quality of the hydrological model simulation results. The formula is as follows:

$$
E=1-\frac{\sum_{t=1}^{T}\left(Q_{o}^{t}-Q_{m}^{t}\right)^{2}}{\sum_{t=1}^{T}\left(Q_{o}^{t}-\overline{Q_{o}}\right)^{2}}
$$

...where $Q_{o}$ refers to the observed value, $Q_{m}$ refers to the predicted value, $Q^{t}$ indicates a certain value at the time of $t$, and $\bar{Q}_{o}$ indicates the average of all observed values. The value of $\mathrm{E}$ ranges from negative infinity to 1 . The value of $\mathrm{E}$ is closer to 1 , the higher the credibility of the model; on the contrary, the lower the reliability of the model. If the value of $\mathrm{E}$ is less than 0 , the model cannot be trusted. All of the above data analysis and graph processing used SPSS 19.0 and Origin 9.0 software.

\section{Results and Discussion}

\section{Characteristics of B. ischaemum Induced by Nitrogen Addition}

Nitrogen, which is the basic element of the synthesis of chlorophyll, nucleic acid synthetic and enzyme, has great effects on plant metabolism and growth [46]. Nitrogen addition would greatly affect the characteristics of B. ischaemum and the coverage, plant height, aboveground biomass and root mass density significantly changed under different nitrogen levels. For the aboveground parts, nitrogen addition promoted tiller capability in B. ischaemum population, hence it increased the plant coverage, aboveground biomass and plant height $(\mathrm{p}<0.05$, Table 2$)$. In this study, the coverage of $B$. ischaemum was ranged from 75.0 to $96.7 \%$ with the mean value of $87.67 \%$. The maximum value was found in the $\mathrm{N}_{10}$ treatment and it was $1.0 \%$ to $28.9 \%$ greater than that of $\mathrm{N}_{0}, \mathrm{~N}_{2.5}$ and $\mathrm{N}_{5}$ treatments. The coverage $(C)$ of $B$. ischaemum increased linearly with the increase of nitrogen amount $(N)(C=2.18 N+$ $\left.78.12, \mathrm{p}<0.01, \mathrm{R}^{2}=0.80\right)$. The aboveground biomass was ranged from 210.0 to $323.0 \mathrm{~g} \cdot \mathrm{m}^{-2}$ with the mean value of $268.9 \mathrm{~g} \cdot \mathrm{m}^{-2}$. Similar to the coverage, the maximum value of the aboveground biomass was detected in the $\mathrm{N}_{10}$ treatment and it was 8.9 to $53.8 \%$ greater than that of $\mathrm{N}_{0}, \mathrm{~N}_{2.5}$ and $\mathrm{N}_{5}$ treatments. The aboveground 
Table 2. Characteristics of $B$. ischaemum under different nitrogen additions.

\begin{tabular}{|c|c|c|c|c|}
\hline Nitrogen treatments & Coverage $\%$ & Plant height $/ \mathrm{cm}$ & Aboveground biomass $/ \mathrm{g} \cdot \mathrm{m}^{-2}$ & Root mass density $/ \mathrm{kg} \cdot \mathrm{m}^{-3}$ \\
\hline $\mathrm{N}_{0}$ & $75.0 \pm 5.0 \mathrm{a}$ & $55.2 \pm 4.1 \mathrm{a}$ & $210.0 \pm 21.9 \mathrm{a}$ & $1.9 \pm 0.3 \mathrm{a}$ \\
\hline $\mathrm{N}_{2.5}$ & $83.3 \pm 2.9 \mathrm{~b}$ & $80.9 \pm 2.1 \mathrm{~b}$ & $245.9 \pm 57.7 \mathrm{ab}$ & $3.0 \pm 0.6 \mathrm{~b}$ \\
\hline $\mathrm{N}_{5}$ & $95.7 \pm 1.2 \mathrm{c}$ & $79.6 \pm 0.9 \mathrm{~b}$ & $296.7 \pm 6.5 \mathrm{bc}$ & $3.2 \pm 0.3 \mathrm{~b}$ \\
\hline $\mathrm{N}_{10}$ & $96.7 \pm 1.5 \mathrm{c}$ & $77.6 \pm 1.8 \mathrm{~b}$ & $323.0 \pm 32.9 \mathrm{c}$ & $1.8 \pm 0.1 \mathrm{a}$ \\
\hline
\end{tabular}

Notes: $\mathrm{N}_{0}, \mathrm{~N}_{2.5}, \mathrm{~N}_{5}$ and $\mathrm{N}_{10}$ refer to the grassplots applied to $0,2.5,5$ and $10 \mathrm{~g} \mathrm{~N} \mathrm{~m}^{-2} \mathrm{yr}^{-1}$, respectively. CK refers to the bare land with no $B$. ischaemum and nitrogen addition. Mean ( \pm S.D.) values of the characteristics of $B$. ischaemum under different nitrogen additions are indicated. Same letters within a column demonstrates there is no significant difference $(\mathrm{p}>0.05)$ between the means of any of the groups tested.

biomass $(A G B)$ of $B$. ischaemum increased linearly with the nitrogen amount $(N)(A G B=11.38 N+219.10$, $\left.\mathrm{p}<0.01, \mathrm{R}^{2}=0.92\right)$. Nitrogen addition can promote plant growth and ecosystem productivity through two ways. For one hand, nitrogen addition increases the macro- and microelement concentrations in plant leaves and then speeds up plant photosynthetic rate [47]. On the other hand, nitrogen addition promotes the growth of aboveground parts and enhance the ability of plants to obtain more other resources, such as water, light and heat resources [48]. For the plant height, it was ranged from 55.2 to $80.9 \mathrm{~cm}$ with the mean value of $73.3 \mathrm{~cm}$. According to the Liebig's law of minimum, many plants limited by nitrogen element at first [46]. Therefore, the nitrogen addition would promote the plant growth and the plant height of $\mathrm{N}_{2.5}, \mathrm{~N}_{5}$ and $\mathrm{N}_{10}$ treatments increased by 40.6 to $46.6 \%$ than that of $\mathrm{N}_{0}$ treatment. But there was no significant difference of plant height among $\mathrm{N}_{2.5}, \mathrm{~N}_{5}$ and $\mathrm{N}_{10}$ treatments.

This was probably because the promoting effect of nitrogen addition on plant aboveground growth was restrained by other factors (such as water and phosphorus) when nitrogen content was saturated [49]. Hogberg et al. also indicated that the promotive effects of nitrogen on stem of boreal forests was disappeared at $10.8 \mathrm{~g} \mathrm{~N} \mathrm{~m}^{-2} \mathrm{yr}^{-1}$ after fertilization for 40 years [50]. In addition, nitrogen addition may promote plant growth initially, while inhibit when the nitrogen addition exceeds plant demands [51]. In this study, this phenomenon was reflected in the belowground parts (i.e. root biomass density). When the nitrogen amount was less than $5 \mathrm{~g} \mathrm{~N} \mathrm{~m}^{-2} \mathrm{yr}^{-1}$, the root mass density increased with nitrogen addition level. The maximum value of root mass density was found in the $\mathrm{N}_{5}$ treatment $\left(3.2 \mathrm{~kg} \cdot \mathrm{m}^{-3}\right)$, which was $6.7 \%$ to $77.8 \%$ greater than that of $\mathrm{N}_{0}, \mathrm{~N}_{2.5}$ and $\mathrm{N}_{10}$ treatments. The root mass density of $\mathrm{N}_{10}$ treatment was the least and even was $5.3 \%$ less than that of $\mathrm{N}_{0}$ treatment. This result indicated that the increase of nitrogen does not always promote root growth. This is probably because when the soil is fertile of nitrogen, the less root would meet the plant growth needs and plants tended to distribute more nutrients to their aboveground parts [52].

\section{Runoff Process Affected by Rainfall Intensity and B. ischaemum Characteristics Induced by Nitrogen Addition}

The rainfall intensity and the varied characteristics of $B$. ischaemum induced by nitrogen addition significantly affected the runoff starting time, which was ranged from 20 to $195 \mathrm{~s}$ (Table 3). The runoff starting time of all treatments was significantly shortened with the increase of rainfall intensity. The average runoff starting time under $1.0 \mathrm{~mm} \mathrm{~min}^{-1}$ rainfall intensity was $120 \mathrm{~s}$ (the maximum, ranged from 40 to $195 \mathrm{~s}$ ), which was increased by by $37.0 \%$ and $66.2 \%$, compared to that of 1.5 and $2.0 \mathrm{~mm} \mathrm{~min}^{-1}$ rainfall intensity. Also, due to the existence of $B$. ischaemum community, runoff starting time was significantly delayed, between 54 and 108 s compared to the bare land $(p<0.05$; Table 3$)$.

Table 3. Runoff starting time of grassplots and bare land (s).

\begin{tabular}{|c|c|c|c|c|c|}
\hline Rainfall intensity $/ \mathrm{mm} \cdot \mathrm{min}^{-1}$ & CK & $\mathrm{N}_{0}$ & $\mathrm{~N}_{2.5}$ & $\mathrm{~N}_{5}$ & $\mathrm{~N}_{10}$ \\
\hline 1.0 & $40 \pm 4.0 \mathrm{a}$ & $90 \pm 8.7 b$ & $125 \pm 4.5 \mathrm{c}$ & $150 \pm 8.7 \mathrm{~d}$ & $195 \pm 8.7 \mathrm{e}$ \\
\hline 1.5 & $27 \pm 5.8 \mathrm{a}$ & $88 \pm 5.8 b$ & $95 \pm 9.3 b$ & $110 \pm 20.0 \mathrm{~b}$ & $118 \pm 40.1 b$ \\
\hline 2.0 & $20 \pm 0.0 \mathrm{a}$ & $72 \pm 42.5 b$ & $76 \pm 6.7 b$ & $95 \pm 10.0 \mathrm{~b}$ & $98 \pm 12.5 b$ \\
\hline Mean values & $29 \pm 9.4 \mathrm{a}$ & $83 \pm 22.5 b$ & $105 \pm 15.7 \mathrm{c}$ & $118 \pm 27.4 \mathrm{c}$ & $137 \pm 49.4 \mathrm{c}$ \\
\hline
\end{tabular}

Notes: $\mathrm{N}_{0}, \mathrm{~N}_{25}, \mathrm{~N}_{5}$ and $\mathrm{N}_{10}$ refer to the grassplots applied to $0,2.5,5$ and $10 \mathrm{~g} \mathrm{~N} \mathrm{~m}^{-2} \mathrm{yr}^{-1}$, respectively. CK refers to the bare land with no $B$. ischaemum and nitrogen addition. Mean ( \pm S.D.) values of the runoff starting time of all treatments are indicated. Same letters within a row demonstrates there is no significant difference $(\mathrm{p}>0.05)$ between the means of any of the groups tested. 


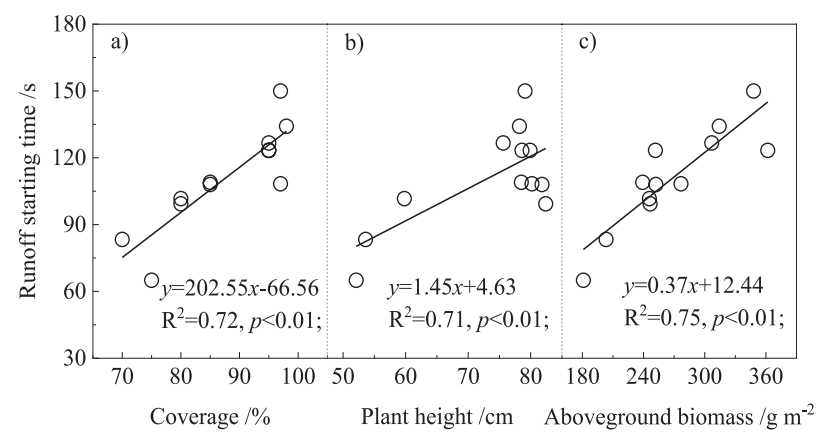

Fig. 1. Runoff starting time as linear functions of a) plant coverage,(b) plant height and c) aboveground biomass.

The mean value of runoff starting time of bare soil was the minimum ( $29 \mathrm{~s})$, and it was decreased by $65.1,72.4$, 75.4 and $78.8 \%$, respectively, compared to that of $\mathrm{N}_{0}$, $\mathrm{N}_{2.5}, \mathrm{~N}_{5}$ and $\mathrm{N}_{10}$ treatments. Vegetation has great effects on the process of runoff generation. During the runoff process, the aboveground parts of B. ischaemum could intercept rainfall and roots growth would promote the infiltration ability, hence delaying the runoff starting time. Moreover, effect of $B$. ischaemum on delaying the runoff starting time was enhanced with the nitrogen addition, and the runoff starting time increased linearly with coverage, plant height and aboveground biomass (Fig. 1). But no significant relationship was found between the runoff starting time and root mass density. This result indicated that the aboveground parts of $B$. ischaemum may play a main role rather than roots for the runoff starting time [53].

The rainfall intensity and nitrogen addition amount also significantly affected the process of runoff. For all treatments, the runoff rates increased rapidly at the first fifteen minutes and tended to be constant at the last fifteen minutes with the rainfall duration (Fig. 2). During this process, the runoff rates of all treatments were significantly increased with the increase of rainfall intensity (Table 4). The mean runoff rates of each treatment under $2.0 \mathrm{~mm} \mathrm{~min}^{-1}$ rainfall intensity ranged from 1.33 to $1.48 \mathrm{~mm} \mathrm{~min}^{-1}$ and were much higher and were 17.5 to $74.1 \%$ and 38.5 to $386.7 \%$ greater than that of 1.5 and $1.0 \mathrm{~mm} \mathrm{~min}^{-1}$ rainfall intensity, respectively. In addition, with the increase of the nitrogen addition, the mean runoff rates in $B$. ischaemum decreased gradually. In spite of the relationship between $B$. ischaemum characteristics and runoff was not significant, the whole effects of $B$. ischaemum on reducing runoff were detected in 1.0 and $1.5 \mathrm{~mm} \cdot \mathrm{min}^{-1}$ rainfall intensity. Compared to the $\mathrm{N}_{0}$ treatment, the mean runoff rates of $\mathrm{N}_{2.5}, \mathrm{~N}_{5}$ and $\mathrm{N}_{10}$ treatments under 1.5 and $1.0 \mathrm{~mm} \mathrm{~min}^{-1}$ rainfall intensities were reduced by 10.5 to $25.4 \%$ and 49.5 to $67.0 \%$, respectively. While for the high rainfall intensity of $2.0 \mathrm{~mm} \cdot \mathrm{min}^{-1}$, although the mean runoff rate increased slightly with the nitrogen addition, there were no significant differences among grassplots. This may be due to the fact that under the high rainfall intensity, the dominant role of vegetation in reducing

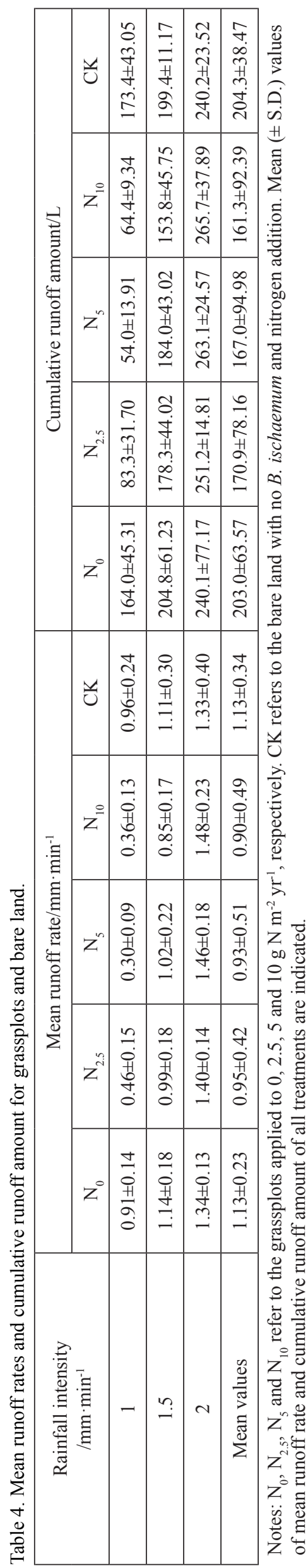




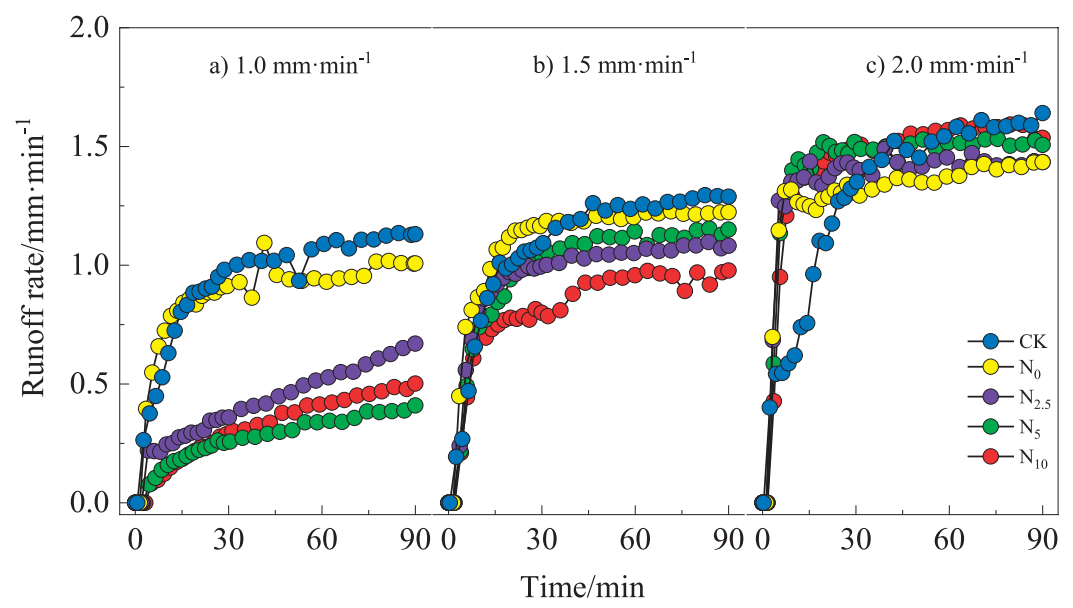

Fig. 2. Runoff rate $\left(\mathrm{mm} \cdot \mathrm{min}^{-1}\right)$ process with rainfall duration time (s) of nitrogen treatments and bare soil under three rainfall intensities a) $1.0 \mathrm{~mm} \mathrm{~min}^{-1}$; b) $1.5 \mathrm{~mm} \mathrm{~min}^{-1}$; c) $2.0 \mathrm{~mm} \mathrm{~min}^{-1} . \mathrm{N}_{0}, \mathrm{~N}_{2.5}, \mathrm{~N}_{5}$ and $\mathrm{N}_{10}$ refer to the grassplots applied to $0,2.5,5$ and $10 \mathrm{~g} \mathrm{~N} \mathrm{~m}^{-2} \mathrm{yr}^{-1}$, respectively. CK refers to the bare land with no $B$. ischaemum and nitrogen addition.

runoff amount was replaced by rainfall intensity [54]. In general, the cumulative runoff amount of $\mathrm{N}_{0}, \mathrm{~N}_{2.5}$, $\mathrm{N}_{5}$ and $\mathrm{N}_{10}$ treatments were 203.0, 170.9, 167.0 and $161.3 \mathrm{~L}$, and compared to the bare soil, they were reduced by $0.7,16.3,18.3$ and $21.1 \%$, respectively. This result demonstrated that vegetation played important role in reducing runoff generation.

\section{Sediment Yield Process Affected by Rainfall} Intensity and $B$. ischaemum Characteristics Induced by Nitrogen Addition

The rainfall intensity and nitrogen addition greatly influenced the process of sediment yield. During rainfall process, the sediment yield rate was increased with rainfall intensity (Fig. 3). Under the $2.0 \mathrm{~mm} \cdot \mathrm{min}^{-1}$ rainfall intensity, the mean sediment yield rates of all treatments ranged from 0.04 to $5.16 \mathrm{~g} \cdot \mathrm{m}^{-2}$ and were 0.3 to $24.7 \%$ and 39.3 to $98.2 \%$ greater than that of
1.5 and $1.0 \mathrm{~mm} \cdot \mathrm{min}^{-1}$ rainfall intensity, respectively (Table 5). With the increase of rainfall intensity, the raindrop kinetic energy enhances, as well as the raindrop impact energy to soil surface. Meanwhile, rainfall intensity also promotes runoff generation, which exacerbates the soil loss. However, due to the existence of $B$. ischaemum, the increase rate of runoff amount was significantly higher than that of sediment yield with the increase of rainfall intensity (Table 4 and Table 5). This led to a decrease in sediment concentration of grassplots $\left(\mathrm{N}_{0}, \mathrm{~N}_{2.5}, \mathrm{~N}_{5}\right.$ and $\mathrm{N}_{10}$ treatments) with the rainfall intensity. Thereinto, the mean sediment concentration under the $2.0 \mathrm{~mm} \cdot \mathrm{min}^{-1}$ rainfall intensity ranged from 0.029 to $0.105 \mathrm{~g} \cdot \mathrm{L}^{-1}$, which was 4.2 to $36.2 \%$ and 5.1 to $59.3 \%$ less than that of 1.5 and $1.0 \mathrm{~mm} \cdot \mathrm{min}^{-1}$, respectively. But the mean sediment concentration of $\mathrm{CK}$ treatment increased with rainfall intensity in the absence of vegetation protection. Under the $2.0 \mathrm{~mm} \cdot \mathrm{min}^{-1}$, it was $3.874 \mathrm{~g} \cdot \mathrm{L}^{-1}$ and was $1.7 \%$

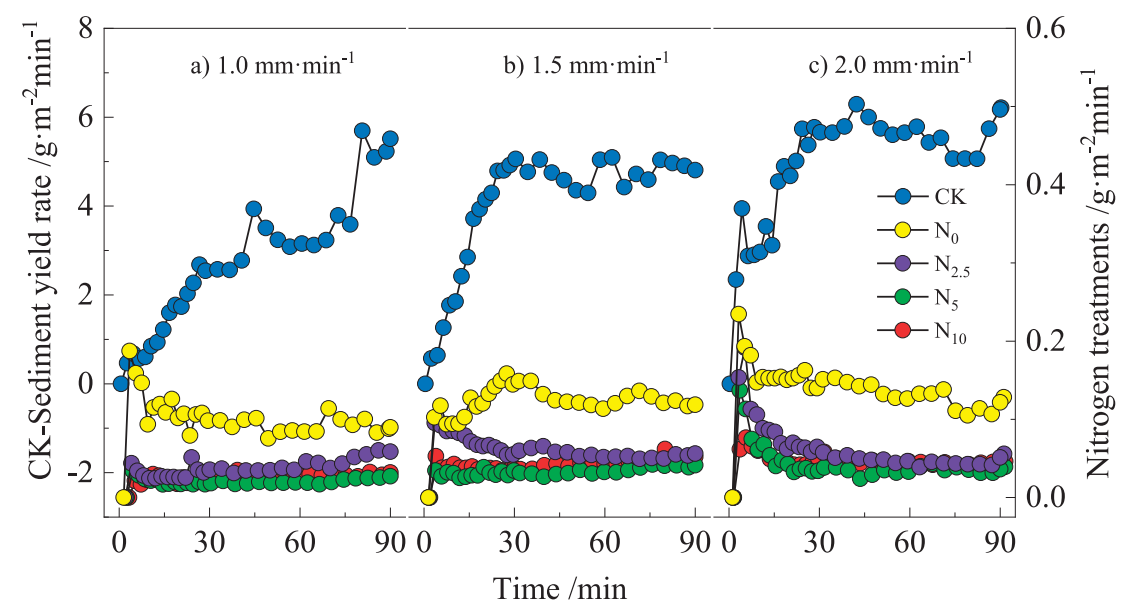

Fig. 3. Sediment yield rate $\left(\mathrm{g} \cdot \mathrm{m}^{-2} \cdot \mathrm{min}^{-1}\right)$ process with rainfall duration time $(\mathrm{s})$ of nitrogen treatments and bare soil under three rainfall intensities a) $1.0 \mathrm{~mm} \mathrm{~min}^{-1}$; b) $1.5 \mathrm{~mm} \mathrm{~min}^{-1}$; c) $2.0 \mathrm{~mm} \mathrm{~min}^{-1} . \mathrm{N}_{0}, \mathrm{~N}_{2.5}, \mathrm{~N}_{5}$ and $\mathrm{N}_{10}$ refer to the grassplots applied to $0,2.5,5 \mathrm{and} 10 \mathrm{~g} \mathrm{~N}$ $\mathrm{m}^{-2} \mathrm{yr}^{-1}$, respectively. CK refers to the bare land with no $B$. ischaemum and nitrogen addition. 


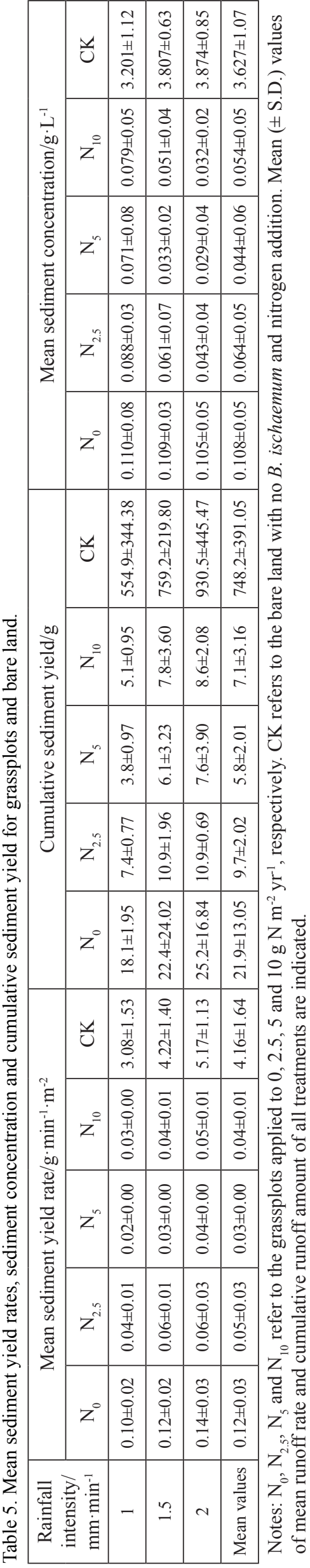

and $21.1 \%$ greater than that of 1.5 and $1.0 \mathrm{~mm} \cdot \mathrm{min}^{-1}$ rainfall intensity. The above results demonstrated that vegetation was an effective factor in inhibiting soil loss. The aboveground parts of B. ischaemum would protect soil from splash erosion, reduce the runoff velocity by increasing the soil surface roughness, and enhance the ability of soil to resist flowing water scouring due to the interaction between root and soil during the process of root growth [55].

Also, nitrogen addition reduced sediment yield through affecting the growth of B. ischaemum in this study. Power functions were found between sediment yield and plant coverage, plant height aboveground biomass or root mass density (Figs 4 and 5), which was consistent with the result of Pan and Shangguan [17]. Besides, some studies indicated that plant roots were more effective than aboveground parts in decreasing sediment yield rate when the soil mass was scoured by flowing water [56]. Especially in the high rainfall intensity condition, the effects of vegetation aboveground parts on sediment tended to be stable or reached the threshold and the sediment reduction was mainly attributed to plant root [57]. In our study, the root mass density for the $\mathrm{N}_{5}$ treatment ( $5 \mathrm{~g} \mathrm{~N}^{-2} \mathrm{~m}^{-2} \mathrm{yr}^{-1}$ ) was the maximum. At the same time, it had the minimum mean sediment yield rate and sediment concentration, which were 18.3 to $73.4 \%$ and 17.8 to $59.1 \%$ less than that of other grassplots, which indicated that plant roots played critical role in the process of soil loss. As reported by other studies, the sediment reduction caused by plant roots of herbage would reduce to $53.7 \%$, and even to $90.0 \%$, for the plant roots would enhance the soil resistance to flowing water by binding the soil mass, improving the soil structure and promoting the soil infiltration ability [8, 15]. Thereby, the effects of B. ischaemum on the sediment yield process with the nitrogen addition level of $5 \mathrm{~g} \mathrm{~m}^{-2} \cdot \mathrm{yr}^{-1}$ might be optimized because of the suitable allocation to aboveground and belowground.
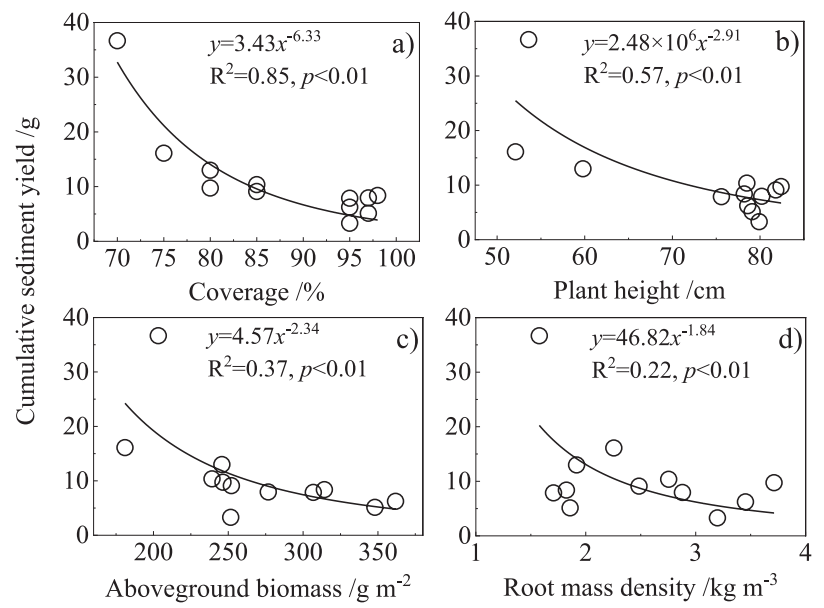

Fig. 4. Cumulative sediment yield as power functions of a) plant coverage, b) plant height, c) aboveground biomass and d) root mass density. 

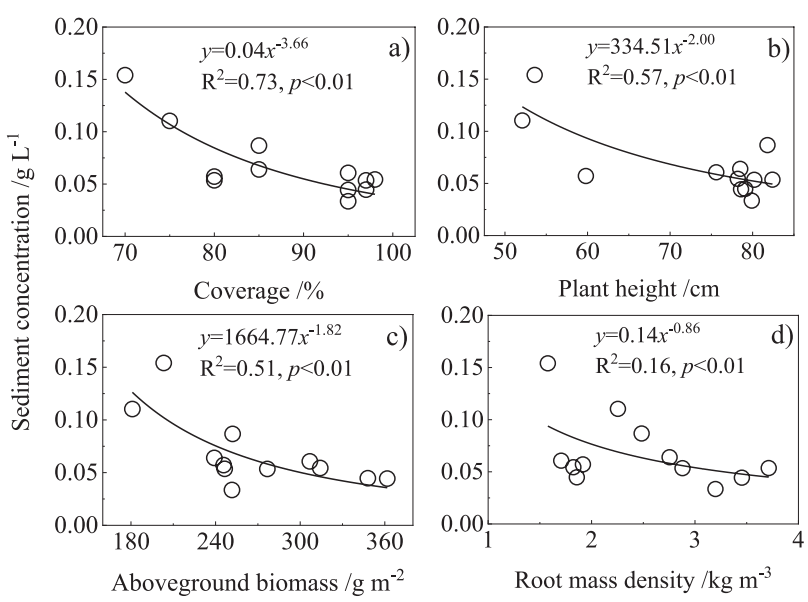

Fig. 5. Sediment concentration as power functions of a) plant coverage, b) plant height, c) aboveground biomass and d) root mass density.

All in all, the order of sediment rates and sediment concentrations under the rainfall intensities of 1.0, 1.5 and $2.0 \mathrm{~mm} \cdot \mathrm{min}^{-1}$ all followed by bare soil $>\mathrm{N}_{0}>\mathrm{N}_{2.5}>$ $\mathrm{N}_{10}>\mathrm{N}_{5}$. Cumulative sediment yields of $\mathrm{N}_{0}, \mathrm{~N}_{2.5}, \mathrm{~N}_{5}$ and $\mathrm{N}_{10}$ treatments were 21.9, 9.7, 5.8 and $7.1 \mathrm{~g}$, respectively, and they were reduced by 97.1, 98.7, 99.2 and 99.0\%, compared to the bare soil (Table 5). All the above results indicated that atmospheric nitrogen deposition may affect the soil erosion process by affecting the growth of grass on the slope.

\section{Relationships between $B$. ischaemum}

Characteristics and the Process of Runoff and Sediment Yield

The characteristics of $B$. ischaemum induced by nitrogen addition would greatly affect the process of runoff and sediment yield. For the runoff generation process, the runoff starting time was positively correlated with the coverage, plant height and aboveground biomass as linear functions $(p<0.01$, Table 6; $0.71 \leq \mathrm{R}^{2} \leq 0.75$, Fig. 1). However, no significant relationship was found between the characteristics of $B$. ischaemum and runoff rate or cumulative runoff $(p>0.05)$. In terms of the processes of sediment yield, cumulative sediment yield and sediment concentration were both negatively correlated with the coverage, plant height, aboveground biomass and root mass density with power functions $\left(p<0.01\right.$, Table $6 ; 0.22 \leq R^{2} \leq 0.85$, $0.16 \leq \mathrm{R}^{2} \leq 0.73$, Fig. 4 and 5). In addition, the interaction between runoff and sediment was also be detected. With the increase of the runoff starting time, the cumulative runoff and cumulative sediment yield all decreased as power functions $(\mathrm{p}<0.01$; Table 6$)$. Besides, the cumulative sediment yield was positively correlated with the cumulative runoff $\left(0.18 \leq R^{2} \leq 0.64\right.$; Fig. 6), while the sediment concentration was negatively correlated with the cumulative runoff ( $\mathrm{p}<0.05$; Table 6$)$. Moreover, the relationship between runoff and sediment also changed due to the varied characteristics in B. ischaemum with different nitrogen addition (Fig. 6). For all treatments, the sediment yield increased with runoff amount with power functions, and this result was consistent with Zhao et al. [54]. Since nitrogen addition improved the morphological characteristics of B. ischaemum, the increase rate of sediment yield with runoff amount was slowed and followed the order of $\mathrm{N}_{0}>\mathrm{N}_{2.5}>\mathrm{N}_{10}>\mathrm{N}_{5}$. It proved once more that the level of $5 \mathrm{~g} \mathrm{~N} \mathrm{~m}^{-2} \mathrm{yr}^{-1}$ was optimal for controlling soil loss.

All in all, in this study, rainfall intensity and nitrogen addition were original factors affect the sediment yield process. The result showed that cumulative sediment yield $(S Y, \mathrm{~g})$ increased with rainfall intensity $\left(R I ; \mathrm{mm} \cdot \mathrm{min}^{-1}\right)$ while it decreased with nitrogen addition

Table 6. Correlation analysis between nitrogen addition, rainfall intensity, characteristics of $B$. ischaemum and runoff and sediment yield.

\begin{tabular}{|c|c|c|c|c|c|c|c|c|c|}
\hline & $\mathrm{RI}$ & $\mathrm{C}$ & $\mathrm{PH}$ & $\mathrm{AGB}$ & $\mathrm{RMD}$ & $\mathrm{IRT}$ & $\mathrm{R}$ & $\mathrm{SY}$ & $S C$ \\
\hline$N$ & 0 & $0.799^{* *}$ & $0.974^{* *}$ & $0.696^{* *}$ & $0.456^{* *}$ & $0.503^{* *}$ & -0.243 & $-0.617^{* *}$ & $-0.452^{* *}$ \\
\hline$R I$ & & 0 & 0 & 0 & 0 & $-0.525^{* *}$ & $0.818^{* *}$ & 0.257 & $-0.509^{* *}$ \\
\hline$C$ & & & $0.766^{* *}$ & $0.848^{* *}$ & 0.177 & $0.545^{* *}$ & -0.246 & $-0.716^{* *}$ & $-0.560^{* *}$ \\
\hline$P H$ & & & & $0.689^{* *}$ & $0.512^{* *}$ & $0.522^{* *}$ & -0.211 & $-0.618^{* *}$ & $-0.484^{* *}$ \\
\hline$A G B$ & & & & & 0.066 & $0.586^{* *}$ & -0.140 & $-0.526^{* *}$ & $-0.452^{* *}$ \\
\hline$R M D$ & & & & & & 0.035 & -0.088 & $-0.380^{*}$ & $-0.339^{*}$ \\
\hline$I R T$ & & & & & & & -0.62 & $-0.663^{* *}$ & -0.137 \\
\hline$R$ & & & & & & & & $0.550^{* *}$ & $-0.359^{*}$ \\
\hline$S Y$ & & & & & & & & $0.582^{* *}$ \\
\hline
\end{tabular}

Note: $N$, nitrogen addition; $R I$, rainfall intensity; $C$, plant coverage; $P \mathrm{H}$, plant height; $A G B$, aboveground biomass; $R M D$, root mass density; $I R T$, runoff starting time;.$R$, runoff amount; $S Y$, sediment yield; $S C$, sediment concentration. ${ }^{*}$ indicates level of significance at $\mathrm{p}<0.05 ;{ }^{* *}$ indicate level of significance at $\mathrm{p}<0.01$. 


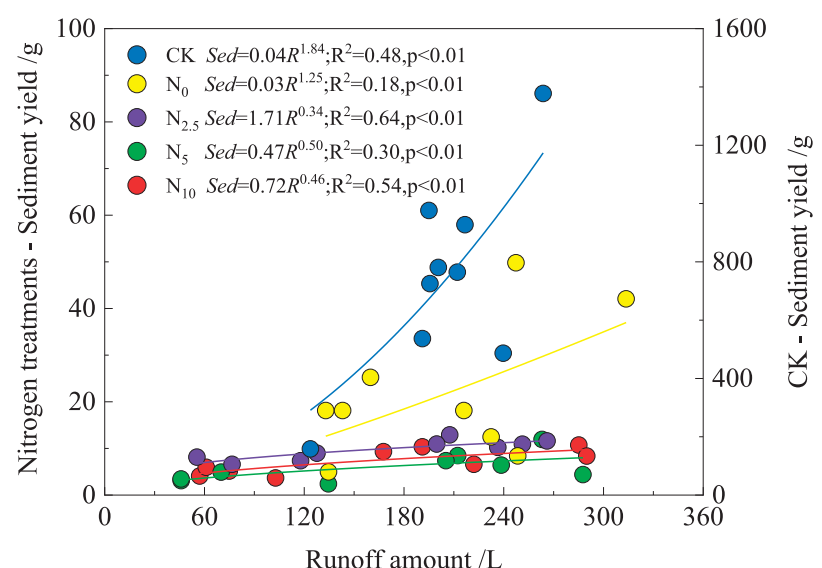

Fig. 6. Cumulative sediment yield as power functions of cumulative runoff amount of nitrogen addition treatments and bare soil treatment. $\mathrm{N}_{0}, \mathrm{~N}_{2.5}, \mathrm{~N}_{5}$ and $\mathrm{N}_{10}$ refer to the grassplots applied to $0,2.5,5$ and $10 \mathrm{~g} \mathrm{~N} \mathrm{~m}^{-2} \mathrm{yr}^{-1}$, respectively. CK refers to the bare land with no $B$. ischaemum and nitrogen addition.

$\left(N ; \mathrm{g} \mathrm{m}^{-2} \cdot \mathrm{yr}^{-1}\right)$ as a power function (Eq. $1 ; \mathrm{R}^{2}=0.45$; $\mathrm{NSE}=0.39$ ).

$$
S Y=10^{-0.308} N^{-0.011} R I^{0.596}
$$

In fact, the characteristics of $B$. ischaemum (coverage, plant height, etc.) and runoff (runoff starting time and runoff amount) were the direct factors affecting sediment yield. It indicated that the cumulative sediment yield (SY; g) increased with cumulative runoff amount $(R ; \mathrm{L})$ but decreased with coverage $(C, \%)$ and root mass density $\left(R B D, \mathrm{~kg} \cdot \mathrm{m}^{-3}\right)$ as a power function (Eq. 2)

$$
S Y=10^{-0.016} C^{-3.463} R B D^{-0.577} R^{0.443}
$$

The performance of Eq. 2 was greatly improved $\left(\mathrm{R}^{2}=0.72 ; \mathrm{NSE}=0.73 ; \mathrm{p}<0.05\right)$ and the results seemed satisfactory.

\section{Conclusions}

The variation of $B$. ischaemum characteristics induced by nitrogen addition can greatly affect the process of soil erosion. This study indicated that nitrogen addition promoted the aboveground parts growth (coverage, plant height, and aboveground biomass) in general. While for plant roots, less root mass would meet plant growth needs when the soil was fertile of nitrogen, hence root mass density of $\mathrm{N}_{10}$ treatment was at the minimum, where it was $5.3 \%$ even less than that of the $\mathrm{N}_{0}$ treatment. Nitrogen addition redistributed the biomass between the plant aboveground and belowground parts, hence affecting the process of runoff and sediment yield. In general, with the nitrogen addition, runoff starting time was delayed and the runoff amount was reduced. The effects of $B$. ischaemum characteristics induced by the nitrogen addition on the runoff tended to be not obvious when the rainfall intensity was high. Although the plant coverage, plant height, aboveground biomass and root mass density were all negatively correlated with sediment yield, the sediment yield would be estimated by plant coverage and root mass density with a power function. While the increase rates of sediment yield with runoff were not with the nitrogen addition increase, due to the redistribution of aboveground and belowground characteristics of $B$. ischaemum induced by the nitrogen addition. The nitrogen addition level of $5 \mathrm{~g} \mathrm{~m}^{-2} \mathrm{yr}^{-1}$ may be optimal for $B$. ischaemum to reduce soil erosion because of the minimum sediment yield.

\section{Acknowledgements}

Financial assistance for this work was provided by the National Natural Science Foundation of China (41771555, 41530858, 41501301), and the National Key Research and Development Program (2016YFC0501703). The authors thank the members of the Ansai Research Station of Soil and Water Conservation, Chinese Academy of Sciences and Ministry of Water Recourses for their technical assistance.

\section{Conflict of Interest}

The authors declare no conflict of interest.

\section{References}

1. GUERRA A.J.T., FULLEN M.A., JORGE M.D., BEZERRA J.F., SHOKR M.S. Slope Processes, Mass Movement and Soil Erosion: A Review. Pedosphere. 27 (1), 27, 2017.

2. MU W.B., YU F.L., LI C.Z., XIE Y.B., TIAN J.Y., LIU J., ZHAO N.N. Effects of rainfall intensity and slope gradient on runoff and soil moisture content on different growing stages of spring maize. Water. 7 (12), 2990, 2015.

3. MOUZAI L., BOUHADEF M. Water drop erosivity: Effects on soil splash. Journal of Hydraulic Research. 41 (1), 61, 2003.

4. SOBOL N.V., GABBASOVA I.M., KOMISSAROV M.A. Effect of rainfall intensity and slope steepness on the development of soil erosion in the Southern Cis-Ural region (A model experiment). Eurasian Soil Science. 50 (9), 1098, 2017.

5. WEN L.L., ZHENG F.L., SHEN H.O., BIAN F., JIANG Y.L. Rainfall intensity and inflow rate effects on hillslope soil erosion in the Mollisol region of Northeast China. Natural Hazards. 79 (1), 381, 2015.

6. WU X.L., WEI Y.J., WANG J.G., XIA J.W., CAI C.F., WEI Z.Y. Effects of soil type and rainfall intensity on sheet erosion processes and sediment characteristics along the climatic gradient in central-south China. Science of the Total Environment. 621, 54. 2018.

7. ZHANG G.H., LIU B.Y., LIU G.B., HE X.W., NEARING M.A. Detachment of undisturbed soil by shallow flow. 
Soil Science Society of America Journal. 67 (3), 713, 2003.

8. WANG B., ZHANG G.H., ZHANG X.C., LI Z.W., SU Z.L., YI T., SHI Y.Y. Effects of near soil surface characteristics on soil detachment by overland flow in a natural succession grassland. Soil Science Society of America Journal. 78 (2), 589, 2014.

9. ZHOU J., FU B.J., GAO G.Y., LU Y.H., LIU Y., LU N., WANG S. Effects of precipitation and restoration vegetation on soil erosion in a semi-arid environment in the Loess Plateau, China. Catena. 137, 1, 2016.

10. FATTET M., FU Y., GHESTEM M., MA W., FOULONNEAU M., NESPOULOUS J., LE BISSONNAIS Y., STOKES A. Effects of vegetation type on soil resistance to erosion: Relationship between aggregate stability and shear strength. Catena. 87, 60, 2011.

11. YANG K.J., LU C.H. Evaluation of land-use change effects on runoff and soil erosion of a hilly basin the Yanhe River in the Chinese Loess Plateau. Land Degradation \& Development. 29 (7), 1211, 2018.

12. EL KATEB H., ZHANG H.F., ZHANG P.C., Mosandl R. Soil erosion and surface runoff on different vegetation covers and slope gradients: A field experiment in Southern Shaanxi Province, China. Catena. 105, 1, 2013.

13. SHI F.S., WANG J.N., LU T., WU Y., GUOCHEN H.X., WU N. Effects of different types of vegetation recovery on runoff and soil erosion on a Wenchuan earthquaketriggered landslide, China. Journal of Soil and Water Conservation. 68 (2), 138, 2013.

14. FENG Q., ZHAO W.W., WANG J., ZHANG X., ZHAO M.Y., ZHONG L.N., LIU Y.X., FANG X.N. Effects of different land-use types on soil erosion under natural rainfall in the Loess Plateau, China. Pedosphere. 26 (2), 243, 2016.

15. WANG B., ZHANG G.H. Quantifying the binding and bonding effects of plant roots on soil detachment by overland flow in 10 typical grasslands on the Loess Plateau. Soil Science Society of America Journal. 81 (6), 1567, 2017.

16. XU G.C., ZHANG J.X., LI P., LI Z.B., LU K.X., WANG X.K., WANG F.C., CHENG Y.T., WANG B. Vegetation restoration projects and their influence on runoff and sediment in China. Ecological Indicators. 95, 233, 2018.

17. PAN C.Z., SHANGGUAN Z.P. Runoff hydraulic characteristics and sediment generation in sloped grassplots under simulated rainfall conditions. Journal of Hydrology. 331 (1-2), 178, 2006.

18. WEN Z.M., LEES B.G., JIAO F., LEI W.N., SHI H.J. Stratified vegetation cover index: A new way to assess vegetation impact on soil erosion. Catena. 83 (1), 87, 2010.

19. ZHU L.Q., ZHU W.B. Research on effects of land use/ cover change on soil erosion. Advanced Materials Research, 433-440, 1038, 2012.

20. WANG B., ZHANG G.H., YANG Y.F., LI P.P., LIU J.X. Response of soil detachment capacity to plant root and soil properties in typical grasslands on the Loess Plateau. Agriculture Ecosystems \& Environment. 266, 68, 2018.

21. ZHANG G.H., LIU G.B., WANG G.L. Effects of canopy and roots of patchy distributed artemisia capillaris on runoff, sediment, and the spatial variability of soil erosion at the plot scale. Soil Science. 177 (6), 409, 2012.

22. XU G.C., LI Z.B., LI P. Fractal features of soil particlesize distribution and total soil nitrogen distribution in a typical watershed in the source area of the middle Dan River, China. Catena. 101, 17, 2013.
23. GAO W.L., YAN D.H. Warming suppresses microbial biomass but enhances $\mathrm{N}$ recycling. Soil Biology \& Biochemistry. 131, 111, 2019.

24. BAI Y.F., WU J.G., CLARK C.M., NAEEM S., PAN Q.M., HUANG J.H., ZHANG L.X., HAN X.G. Tradeoffs and thresholds in the effects of nitrogen addition on biodiversity and ecosystem functioning: evidence from inner Mongolia Grasslands. Global Change Biology. 16 (1), 358, 2010.

25. BOUTIN M., CORCKET E., ALARD D., VILLAR L., JIMENEZ J.J., BLAIX C., LEMAIRE C., CORRIOL G., LAMAZE T., PORNON A. Nitrogen deposition and climate change have increased vascular plant species richness and altered the composition of grazed subalpine grasslands. Journal of Ecology. 105 (5), 1199, 2017.

26. PAYNE R.J., DISE N.B., FIELD C.D., DORE A.J., CAPORN S.J.M., STEVENS C.J. Nitrogen deposition and plant biodiversity: past, present, and future. Frontiers in Ecology and the Environment. 15 (8), 431, 2017.

27. STEVENS C.J., LIND E.M., HAUTIER Y., HARPOLE W.S., BORER E.T., HOBBIE S., SEABLOOM E.W., LADWIG L., BAKKER J.D., CHU C., COLLINS S., DAVIES K.F., FIRN J., HILLEBRAND H., LA PIERRE K.J., MACDOUGALL A., MELBOURNE B., MCCULLEY R.L., MORGAN J., ORROCK J.L., PROBER S.M., RISCH A.C., SCHUETZ M., WRAGG P.D. Anthropogenic nitrogen deposition predicts local grassland primary production worldwide. Ecology. 96 (6), 1459.2015.

28. WANG C.T., LONG R.J., WANG Q.L., LIU W., JING Z.C., ZHANG L. Fertilization and litter effects on the functional group biomass, species diversity of plants, microbial biomass, and enzyme activity of two alpine meadow communities. Plant and Soil. 331 (1-2), 377, 2010.

29. ZHANG M.L., LAL R., ZHAO Y.Y., JIANG W.L., CHEN Q.G. Spatial and temporal variability in the net primary production of grassland in China and its relation to climate factors. Plant Ecology. 218 (9), 1117, 2017.

30. TANG Z.S., DENG L., AN H., YAN W.M., SHANGGUAN Z.P. The effect of nitrogen addition on community structure and productivity in grasslands: A meta-analysis. Ecological Engineering. 99, 31, 2017.

31. LENNON J.M., ABER J.D., MELILLO J.M. Primary production and nitrogen allocation of field grown sugar maples in relation to nitrogen availability. Biogeochemistry. 1 (2), 135, 1985.

32. LADWIG L.M., COLLINS S.L., SWANN A.L., XIA Y., ALLEN M.F., ALLEN E.B. Above- and belowground responses to nitrogen addition in a Chihuahuan Desert grassland. Oecologia. 169 (1), 177, 2012.

33. WANG G.L., FAHEY T.J., XUE S., LIU F. Root morphology and architecture respond to $\mathrm{N}$ addition in Pinus tabuliformis, west China. Oecologia. 171 (2), 583, 2013.

34. XU X.T., LIU H.Y., SONG Z.L., WANG W., HU G.Z., QI Z.H. Response of aboveground biomass and diversity to nitrogen addition along a degradation gradient in the Inner Mongolian steppe, China. Scientific Reports. 5, 10284, 2015.

35. ZHANG X.C., LIU W.Z. Simulating potential response of hydrology, soil erosion, and crop productivity to climate change in Changwu tableland region on the Loess Plateau of China. Agricultural and Forest Meteorology. 127 (3-4), 136, 2005.

36. CHEN L.D., WEI W., FU B.J., LU Y.H. Soil and water conservation on the Loess Plateau in China: review and 
perspective. Progress in Physical Geography-Earth and Environment. 31 (4), 389, 2007.

37. LI J.J., LI Z., LU Z.M. Analysis of spatiotemporal variations in land use on the Loess Plateau of China during 1986-2010. Environmental Earth Sciences. 75 (11), 997, 2016.

38. GALLOWAY J.N., DENTENER F.J., CAPONE D.G., BOYER E.W., HOWARTH R.W., SEITZINGER S.P., ASNER G.P., CLEVELAND C.C., GREEN P.A., HOLLAND E.A., KARL D.M., MICHAELS A.F., PORTER J.H., TOWNSEND A.R., VOROSMARTY C.J. Nitrogen cycles: past, present, and future. Biogeochemistry. 70 (2), 153, 2004.

39. BOBBINK R., HICKS K., GALLOWAY J., SPRANGER T., ALKEMADE R., ASHMORE M., BUSTAMANTE M., CINDERBY S., DAVIDSON E., DENTENER F., EMMETT B., ERISMAN J.W., FENN M., GILLIAM F., NORDIN A., PARDO L., DE VRIES W. Global assessment of nitrogen deposition effects on terrestrial plant diversity: a synthesis. Ecological Applications. 20 (1), 30, 2010.

40. JIA Y.L., YU G.R., GAO Y.N., HE N.P., WANG Q.F., JIAO C.C., ZUO Y. Global inorganic nitrogen dry deposition inferred from ground- and space-based measurements. Scientific Reports. 6, 19810, 2016.

41. ZHU J.X., HE N.P., WANG Q.F., YUAN G.F., WEN D., YU G.R., JIA Y.L. The composition, spatial patterns, and influencing factors of atmospheric wet nitrogen deposition in Chinese terrestrial ecosystems. Science of the Total Environment. 511, 777, 2015.

42. WEI Y., TONG Y.A., QIAO L., LIU X.J., DUAN M., LI J. Preliminary estimate of the atmospheric nitrogen deposition in different ecological regions of Shaanxi Province. Journal of Agro-Environent Science. 29 (4), 795, 2010 [In Chinese].

43. BOBBINK R., HICKS K., GALLOWAY J., SPRANGER T., ALKEMADE R., ASHMORE M., BUSTAMANTE M., CINDERBY S., DAVIDSON E., DENTENER F., EMMETT B., ERISMAN J.W., FENN M., GILLIAM F., NORDIN A., PARDO L., DE VRIES W. Global assessment of nitrogen deposition effects on terrestrial plant diversity: a synthesis. Ecological Applications. 20 (1), 30-59. 2010.

44. GALLOWAY J.N., DENTENER F.J., CAPONE D.G., BOYER E.W., HOWARTH R.W., SEITZINGER S.P., ASNER G.P., CLEVELAND C.C., GREEN P.A., HOLLAND E.A., KARL D.M., MICHAELS A.F., PORTER J.H., TOWNSEND A.R., VOROSMARTY C.J. Nitrogen cycles: past, present, and future. Biogeochemistry. 70 (2), 153, 2004.

45. LIU X.J., ZHANG Y., HAN W.X., TANG A.H., SHEN J.L., CUI Z.L., VITOUSEK P., ERISMAN J.W., GOULDING K., CHRISTIE P., FANGMEIER A., ZHANG F.S. Enhanced nitrogen deposition over China. Nature. 494 (7438), 459, 2013.
46. ZHANG Q., XIONG G.M., LI J.X., LU Z.J., LI Y.L., XU W.T., WANG Y., ZHAO C.M., TANG Z.Y., XIE Z.Q. Nitrogen and phosphorus concentrations and allocation strategies among shrub organs: the effects of plant growth forms and nitrogen-fixation types. Plant and Soil. 427 (1-2), 305, 2018.

47. AI Z.M., WANG G.L., LIANG C.T., LIU H.F., ZHANG J.Y., XUE S., LIU G.B. The Effects of Nitrogen Addition on the Uptake and Allocation of Macro- and Micronutrients in Bothriochloa ischaemum on Loess Plateau in China. Frontiers in Plant Science. 8, 1476, 2017.

48. XU X.N., YAN L.M., XIA J.Y. A threefold difference in plant growth response to nitrogen addition between the laboratory and field experiments. Ecosphere. 10 (1), 2019.

49. SONG C.J., MA K.M., QU L.Y., LIU Y., XU X.L., FU B.J., ZHONG J.F. Interactive effects of water, nitrogen and phosphorus on the growth, biomass partitioning and water-use efficiency of Bauhinia faberi seedlings. Journal of Arid Environments. 74 (9), 1003, 2010.

50. HOGBERG P., FAN H.B., QUIST M., BINKLEY D., TAMM C.O. Tree growth and soil acidification in response to 30 years of experimental nitrogen loading on boreal forest. Global Change Biology. 12 (3), 489, 2006.

51. TIAN D.H., WANG H., SUN J., NIU S.L. Global evidence on nitrogen saturation of terrestrial ecosystem net primary productivity. Environmental Research Letters. 11 (2), 2016.

52. MIESEL J.R., JACH-SMITH L.C., RENZ M.J., JACKSON R.D. Distribution of switchgrass (Panicumvirgatum L.) aboveground biomass in response to nitrogen addition and across harvest dates. Biomass and Bioenergy. 100, 74, 2017.

53. ZHANG G.H., LIU G.B., ZHANG P.C., YI L. Influence of vegetation parameters on runoff and sediment characteristics in patterned Artemisia capillaris plots. Journal of Arid Land. 6 (3), 352, 2014.

54. ZHAO X.N., CHEN X.L., HUANG J., WU P.T., HELMERS M.J. Effects of vegetation cover of natural grassland on runoff and sediment yield in loess hilly region of China. Journal of the Science of Food and Agriculture. 94 (3), 497, 2014.

55. PAN C.Z., MA L., WAINWRIGHT J., SHANGGUAN Z.P. Overland flow resistances on varying slope gradients and partitioning on grassed slopes under simulated rainfall. Water Resources Research. 52 (4), 2490, 2016.

56. LI C.J., PAN C.Z. The relative importance of different grass components in controlling runoff and erosion on a hillslope under simulated rainfall. Journal of Hydrology. 558, 90, 2018.

57. LIU Q., ZHU B., TANG J.L., HUANG W.J., ZHANG X.F. Hydrological processes and sediment yields from hillslope croplands of regosol under different slope gradients. Soil Science Society of America Journal. 81 (6), 1517, 2017. 